\title{
DIVINE LOGOS IN THE HEART OF BOETHIUS'S PATH TOWARD SUMMUM BONUM
}

\author{
El Logos divino en el anhelo de Boecio hacia el Summum Bonum. \\ Agnieszka Kijewska \\ Universidad Católica Juan Pablo II de Lublin (Polonia)
}

\section{RESUMEN}

Este artículo presenta un esbozo del modo en que Boecio concebía el camino humano hacia el Bien Supremo (Summum Bonum). Con el fin de lograr este objetivo, primero hay que especificar la forma en que construye este verdadero Bien Supremo y esta discusión está naturalmente relacionada con el problema más discutido que ataña a la identidad cristiana de Boecio: ¿era realmente Cristiano? Su Consolatio, desde la cual cualquier alusión patente a la fe Cristiana está ausente, ¿nos abastece con algún indicio sobre el hecho de si el Bien Supremo de Boecio puede ser identificado con el Dios del Evangelio? En el curso del análisis nos proponemos una hipótesis, según la cual el mensaje que Boecio propone a través de los significados de su Consolatio y las expresiones que él pone en boca de su Dama Filosofía no están tan lejos del consejo ofrecido por Fulgentius de Proba. Ella, también, fue animada a reconocer su misma debilidad y falta de suficiencia, su arrepentimiento, su humilde fe en la sabiduría y en la guía de Dios, quien es de todos el mejor de los doctores. ¿Es este mensaje parecido al de la filosofía de Dame? Alcuino, quien se consideraba como un fiel «discípulo» de Boecio, ¿compartía un concepto de filosofía como el «maestro de virtudes» y sabiduría, como aquel que conduce al hombre a lo largo del camino de la sabiduría hacia la luz Divina?

Palabras clave: Bien Supremo, ascensión espiritual, Fulgencio de Ruspe, filosofía como medicina, Boecio.

\begin{abstract}
This paper presents an outline of the way Boethius conceived the human path to the Supreme Good (Summum Bonum). In order to achieve this goal one has first to specify the way he construed this Supreme Good, and this discussion is naturally related to the much-discussed problem concerning the Christian identity of Boethius: was he indeed a Christian? Does his Consolation, from which any overt allusions to Christian faith are absent, provide us with any clue as to whether the Supreme Good of Boethius can be identified with the God of the Gospel? In the course of the analysis we propound a hypothesis that the message that Boethius puts forward through the means of his Consolation and the utterances he puts in the mouth of his Dame Philosophy are not far removed from the advice offered by Fulgentius to Proba. She, too, was encouraged to acknowledge her own weakness and lack of sufficiency, to be contrite, and to have humble trust in wisdom and guidance of God, who is the best of all doctors. Is Dame Philosophy's message not very similar? Did not Alcuin, who regarded himself as a faithful «disciple» of Boethius, share a conception of philosophy as being the «teacher of virtues» and wisdom, as the one who leads man along the path of wisdom towards the Divine light?
\end{abstract}

Keywords: Supreme Good, spiritual ascent, Fulgentius of Ruspe, Philosophy as a medicine, Boethius.

1. In order to present an outline of the way Boethius conceived the human path to the Supreme Good (Summum Bonum), the path that he so evocatively described in his Consolation of philosophy, one has first to specify the way he construed this very Supreme 
Good. ${ }^{1}$ The discussion of Boethius' understanding of the Supreme Good is naturally related to the much discussed problem concerning the Christian identity of Boethius: was he indeed a Christian? ${ }^{2}$ Does his Consolation, from which any overt allusions to Christian faith are absent, provide us with any clue as to whether the Supreme Good of Boethius can be identified with the God of the Gospel?

The debate concerning the Christian identity of Boethius was started in the $10^{\text {th }}$ century by Bovo of Corvey, who in his commentary to the ninth meter of book three of the Consolation (O qui perpetua) inquired why towards the end of his life Boethius had written a work containing statements that contradicted the catholic faith. ${ }^{3}$ This controversy underwent various phases and it took a new, dramatic turn in the $19^{\text {th }}$ century, as historians and philologists took over from theologians and philosophers. The positions of $20^{\text {th }}$ century scholars on this issue were divided by John Marenbon into three groups: (1) those, who «christianize» Boethius, (2) «Augustinists», (3) «Hellenists». ${ }^{4}$ Marenbon mentions Friedrich Klinger as a typical representative of the first group. Klinger reads the De Consolatione as a sacred dialogue, in which Lady Philosophy, as God's Angel, leads Boethius to God. ${ }^{5}$ My belief is that Romano Cessario's suggestion expressed in his Boethius, Christ and the New Order to the effect that Boethius' decisive contribution to the development of Europe was precisely the result of his sharing in the Christian inspiration without which the spiritual community of Europe would have been unthinkable, should also be placed in the first group identified by Marenbon. ${ }^{6}$

The second group includes those who introduce St. Augustine into the debate by pointing to the fact that his way to the full embracing of Christianity lead through his study of «the books of the Platonists» (libri platonicorum), thus pointing to the fact that the relationship of Platonism and Christianity need not be necessarily construed as one of unbridgeable opposition. In this group belongs Henry Chadwick, whose book Boethius. The Consolation of Music, Logic, Theology, and Philosophy has already become a classic, in which he states that the De Consolatione is a work of a Platonist who nonetheless is also a Christian. Boethius was writing it as though Augustine himself stood watching him from behind his back: what resulted was a confession of faith of a Platonist, which, however contained nothing that Augustine himself - the author of philosophical dialogues and the Confessions - would find

1 Cf. Kijewska, A., «Boethius' Conception of the Supreme Good», in A. Kijewska (ed.), Being or Good. Metamorphoses of Neoplatonism, Lublin, Wydawnictwo KUL, 2004, pp. 307-317.

2 Cf. Kijewska, A., Filozof i jego muzy. Antropologia Boecjusza-jej źródła i recepcja, Kęty, Wydawnictwo Marek Derewiecki, 2011, p. $50 \mathrm{ff}$.

3 Cf. Bovo von Korvei, «Kommentar zum O qui perpetua» III, R. B. C. Huyghens (ed.), CCCM 171, Turnholti, Brepols, 2000, p. 100: «Quisquis illorum Boetii versuum intelligentiam indagare cupit [...], inprimis admonendus est non solum in his versibus, sed et in multis locis eiusdem operis, quod Consolationis Philosophiae titulo prenotatur, quaedam catholicae fidei contraria repperiri; quod ideo mirum est, quia libellum quendam eiusdem auctoris de sancta Trinitate valde praeclarum legi, et alium contra Euticen et Nestorium haereticos, quos $\mathrm{ab}$ eodem esse conscriptos quisque aliis eius libris legendis operam inpendit, ut ego ab adolescentia feci, ex ipso elegantis stili quodam proprio nitore indubitanter agnoscit. Quod tamen utcumque se habeat, certum est eum in his libris nihil de doctrina ecclesiastica disputasse, sed tantum philosophorum et maxime Platonicorum dogmata legentibus aperire voluisse. Unde se ubique interrogantem, ipsam vero philosophiam respondentem docentemque introducit».

4 Cf. Marenbon, J., Boethius, Oxford, Oxford University Press, 2003, p. 156 ff.

5 Cf. Klingner, F., De Boethii Consolatione Philosophiae, Berlin, Weidmann, Philologische Untersuchungen 27, 1921 (reprint: Zurich-Dublin, 1966), 117 [after: Marenbon, J., Boethius, p. 156].

6 Cf. Cessario, R., «Boethius, Christ and the New Order», in N. H. Kaylor, P. E. Phillips (eds.), New Directions in Boethian Studies, Kalamazoo, Michigan, Studies in Medieval Culture XLV, Medieval Institute Publications, 2007, p. 158. 
unacceptable. ${ }^{7}$ Edmund Silk can be regarded as another representative of Marenbon's second group of scholars of Boethius; while acknowledging that no certainty can be obtained as to whether Boethius had been familiar with Augustine's dialogues, he draws a number of suggestive parallels between the Consolation and the Cassiciacum dialogues. One of those parallels concerns a conception of philosophy to be found in both writers: philosophy is referred to as healing spiritual diseases and a guide leading the progress towards the Supreme Good. ${ }^{8}$

The last group of Boethius' scholars identified by Marenbon is described as «Hellenists», the leading figure in this group being Pierre Courcelle. Without questioning Boethius' authentically Christian outlook, he nevertheless lays the stress on his Neoplatonist stance; in his eyes Boethius strove to implant the philosophical teaching of Ammonius and Proclus in Rome, while upholding the separation of the spheres of reason and faith. ${ }^{9}$ In my opinion, in this group also belong Danuta Shanzer ${ }^{10}$ and Alain Galonnier; the last named regards Boethius as the founder of a program of Platonic-Aristotelian syncretism, designed to incorporate the most valuable achievements of ancient Greek thought and make them available to the Latin-speaking world. ${ }^{11}$

In what follows, I would like to propose an interpretation of the Consolation of Philosophy in the spirit of the «Augustinist» approach. This interpretation can accept as its own the following words of Fabio Troncarelli concerning Boethius' attitude:

«The philosopher - he writes - turns to God, with the language and the manner which he instinctively considers to be the most adapted. He does not speak to a God whom he ignores and who ignores him: he speaks affectionately, despairingly, passionately, to the divinity which he has all his life tried to understand and define, through the most refined terminology and culture of his time. In this light, Christianity, this legacy of raw religious emotions, was not forgotten or rejected: it is rather re-elaborated, as it has always been in the past». ${ }^{12}$

I share in the belief of those who think the minds of both St. Augustine and Boethius became a meeting place between authentic Christianity and a legacy of Ancient intellectual culture, predominantly Platonist and Neoplatonist..$^{13}$ Certainly, the two men were not quite like each other, there were differences in the social status, historical circumstances, education, life vocation, interests and times in which they lived. For all that, one cannot but acknowledge that their respective visions of God and the conception of the way by which human beings can reach Him are very much alike. As Troncarelli puts it «he (Augustine) too was inspired by

7 Cfr. Chadwick, H., Boethius. The Consolations of Music, Logic, Theology and Philosophy, Oxford, Clarendon Press, 1981, p. 249.

8 Cf. Silk, E. T., Boethius's «Consolatio Philosophiae as a Sequel to Augustine's Dialogues and Soliloquia», in Harvard Theological Review, 32/ 1 (1939), pp. 21-25. Silk asserts that although it cannot be proven that Boethius knew Augustine's dialogues, it is very likely that he did because they were kept at Cassiodorus' Vivarium library among other sites (cf. there, pp. 38-39).

9 Cf. Courcelle, P., La «Consolation de la Philosophie» dans la tradition littéraire. Antécédents et Posterité de Boèce, Paris, Etudes Augustiniennes, 1967, pp. 339-341.

10 Cf. Shanzer, D., «Interpreting the Consolation», in J. Marenbon (ed.). The Cambridge Companion to Boethius, Cambridge, Cambridge University Press, 2009, pp. 240-241; cf. Shanzer, D., «Haec quibus uteris verba: The Bible and Boethius' Christianity», in N. E. Lensky, A. Cain (eds.), The Power of Religion in Late Antiquity, Farnham/Burlington, Ashgate, 2009, pp. 64-66.

11 Cf. Galonnier, A., Boèce. Opuscula sacra, vol. 1: Capita dogmatica, (Traites II, III, IV), Louvain-laNeuve/Leuven/Paris, 2007, pp. 135-137.

12 Troncarelli, F., «Afterword: Boethius in Late Antiquity and the Early Middle Ages», in N. H. Kaylor, P. E. Phillips (eds.), A Companion to Boethius in the Middle Ages, Leiden-Boston, Brill, 2012, p. 526.

13 Cf. ibíd., p. 525. 
Platonism, which brought out the purely contemplative aspect of the relationship with the divine, the predominantly intellectual dimension of that relationship, which saints such as St. Francis would understand with great difficulty - just as he would perhaps have difficulty in understanding the Soliloquia, in which Augustine converses with his own reason exactly as Boethius does with philosophy. Exactly as Boethius, he does not refer to the name of Christ, not even when he prays, with moved emphasis, to a God, defined in similar terms to those used by Boethius, "my home, my motherland, my salvation, my light, my life"».14

Boethius pointed himself to his Augustinian legacy, when, in the preface to his treatise De Trinitate, he acknowledges the fundamental influence Augustine's works exerted upon his mind. ${ }^{15}$ Possibly, that influence could have reached him via diverse paths, including indirect ones, such as the cultural milieu he was a member of, known as the «circle of Symmachus». This association has been compared by Henry Chadwick to a similar circle of Christians of Neoplatonist leanings that gathered around St. Ambrose, Simplicianus and Manlius Theodorus in Milan at the time Augustine sojourned in that city. ${ }^{16}$ One of the ecclesiastics and intellectuals who addressed the party of Roman aristocrats assembled around Symmachus was Fulgentius, the bishop of Ruspe, whose pastoral ideas were permeated with St. Augustine's spirit.

2. Fulgentius of Ruspe was probably born in 467 in Thelepte in Roman Africa (modern Tunisia). He was given a thorough classical training in Latin and Greek, he was even reputed to know all Homer by heart. As a procurator of Byzacena he not only performed his administrative duties (tax collecting) but also devoted himself to studying St. Augustine. In time he came to embrace Catholic faith and took on a monk's frock. ${ }^{17}$ Yet Africa in those days was in the hands of Arian Vandals, and the Vandal king Trasamund persecuted catholics, so Fulgentius was forced to leave. He contemplated going to the Egyptian desert and he made a pilgrimage to Rome. Having returned to his native Africa, he was made bishop of Ruspe, against his wish, just as in the case of St. Augustine. A new persecution by Trasamund for the second time drives him away from Africa, to Sardinia, where, in 510 - 523 he composed his famous ascetical epistles. ${ }^{18}$ These were exactly the years that saw the flourishing of Boethius' political career.

Fulgentius' letters, even though addressed to specific persons, members of Roman aristocracy, served the purpose of providing spiritual guidance for the whole milieu and can with justice be considered as opuscula spiritualia of a sort. ${ }^{19}$ At least some of the addressees were members of the intimate circle where Boethius belonged: for instance the second letter in the cycle is addressed to Galla, the widowed sister of Boethius' wife Rusticiana. ${ }^{20}$ The spiritual advice contained therein is characteristic: she is being admonished not to take too much pride in her aristocratic descent: even if her grandfather, father, husband, and father-inlaw distinguished themselves as consuls, she ought to strive to acquire greatness through the virtue of humility. ${ }^{21}$ Galla's father was Quintus Aurelius Memmius Symmachus, whom Cassiodorus described as a «follower of the ancient Cato, who however surpassed the virtues

14 Ibíd., p. 524.

15 Cf. Boethius, De Trinitate, H. F. Stewart, E. K. Rand (eds.), Cambridge Mas., Harvard University Press, 1968, p. 4: «Vobis tamen etiam illud inspiciendum est, an ex beati Augustini scriptis semina rationum aliquos in nos venientia fructus extulerint».

16 Cf. Chadwick, H., o.c., p. 16.

17 Cf. Bachelet, D., Introduction, in Fulgence de Ruspe, Lettres ascétiques et morales, texte critique J. Fraipont, introd., traduction. et notes D. Bachelet, Paris, SCh 487, Cerf, 2004, p. 10.

18 Ibíd., p. 11.

19 Ibíd., p. 23.

20 Ibíd., pp. 17-18.

21 Fulgence de Ruspe, Lettres ascétiques et morales II, 32, 138-139. 
of the ancients by the sanctity of his religion». ${ }^{22}$ Symmachus, probably in 487, adopted Boethius, who had been orphaned as a child and later became his father-in-law, when Boethius married Rusticiana, another daughter of Symmachus.

Fulgentius' third and fourth letters are destined for Proba, who is eulogized as a «paradigm of virginity and humility» (virginitatis et humilitatis exemplar) and who is designated as «Galla's sister». ${ }^{23}$ This designation perhaps need not be construed literally, yet, even if Proba was not Galla's own sister, she must have been closely related, by blood as well as spiritual affinity. ${ }^{24}$ Fulgentius' fifth epistle was addressed to Eugippius, who must also have been related to Symmachus and his circle, as his monumental anthology of 348 excerpts from St. Augustine, compiled for Proba, bears out. ${ }^{25}$ The sixth letter was destined for Theodorus, a senator and a scion of the family of the Decii, whose brothers also held senatorial dignities; one of them was the senator Albinus ${ }^{26}$ (mentioned in the De Consolatione Philosophiae). The seventh epistle Fulgentius addressed to Venantia, probably another scion of the Decii. ${ }^{27}$

The content of Fulgentius' letters is always principled Christian admonition, guidance and consolation, it is coached in such terms as to make it applicable to any reader interested in spiritual advice; while speaking to a given addressee, he seems to bear in mind a broader audience of followers, and his epistles are in fact little treatises aiming at strengthening the Christian resolve of his correspondents. They are permeated with the spirit of St. Augustine and based on firm scriptural foundations. In contrast to Boethius, Fulgentius does not make in his letters many classical references, instead he copiously quotes the Bible. ${ }^{28}$

Fulgentius, an «expert in exile», ${ }^{29}$ comforts Galla's sorrow after the loss of her husband; he strengthens her resolve to persevere in the way of life she has chosen, that is the arduous way of widowhood, reminds her of the guiding presence of the One who is the way, the truth and the life (cf. John 14,6), who knows how to offer the gift of eternal joy to His faithful using momentary sorrows, transferring them in his paternal kindness from this world to the kingdom of heaven. ${ }^{30}$ God's dispensation, continues the bishop, by which Galla's husband has been

22 Cf. Cassiodorus, Excerpta ex libello Cassiodori, in A. Galonnier, o.c., p. 78: «Symmachus patricius et consul ordinarius, vir philosophus, qui antiqui Catonis fuit novellas imitator, sed virtutes veterum sanctissima religione transcendit».

23 Fulgence de Ruspe, Lettres ascetiques et morales II, 31, 138-139.

24 This is Galonnier's suggestion: cf. Galonnier, A., o.c., 55, 235-236.

25 Cf. Index rerum et verborum, PL 70, 1438: «Eugipius abbas, ex operibus divi Augustini, librum confecit, et Probae virgini dedicavit».

26 Cf. D. Bachelet, D., Introduction, pp. 19-20. Cf. Moorhead, J., Theoderic in Italy, Oxford, Clarendon Press, 1992, p. 208: «During the second period of exile, that is approximately $518-23$, Fulgentius corresponded with Galla, a daughter of the senator Symmachus, and another woman whom he described to Galla as "your sister Proba, the holy virgin of Christ"; if the reference to Proba as the sister of Galla is to be taken literally, as it probably is, Fulgentius corresponded with two sisters-in-law of Boethius. His correspondents included a consul of the golden first decade of the century, Theodorus, as well as Eugippius, abbot of the monastery which grew up around the relics of St. Severin at Lucullanum and, as we have seen, a friend of the deacon Paschasius, an adherent of Laurentius and Dionysius Exiguus». Cf. Idem, «The Decii under Theoderic», in Historia: Zeitschrift für Alte Geschichte, 33/1 (1984), p. 110.

27 Cf. Bachelet, D., Introduction, pp. 20-21.

28 Ibid., pp. 23, 29

29 Ibíd., p. 26.

30 Cf. Fulgence de Ruspe, Lettres ascétiques et morales II, 1, p. 104: «Ante menses aliquot diaconi mei ex urbe remeantis certa narratione comperi, non solum tui coniugis obitum, verum etiam sanctum propositi tui tramitem, in quo iam ambulas, illo deducente qui est via, veritas et vita, qui fidelibus suis novit per momentaneam tristitiam donum sempiternae largiri laetitiae, et quos vult salubriter de terrenis ad caelestia paternae benignitatis dispensatione, transferre». 
transferred to a heavenly abode, is unfathomable, yet profoundly meaningful: her husband has been offered eternal joy and herself given an opportunity to live a better life than the one she lived previously. ${ }^{31}$ The saintly bishop has a very definite view of the value of diverse kinds of life open to man: married life comes lowest in the hierarchy, even though he follows Augustine in appreciating and extolling the goodness and dignity of marriage, widowhood comes next; the top of the hierarchy occupies virginity as the noblest kind of life; Galla will find a good example of this perfect kind of life in her sister Proba. Fulgentius' consolation continues with the words of St. Paul from 1 Thessalonians 4, 13-14 where the Apostle encourages his addressees not to despair overmuch over the death of dear ones, given the hope of their resurrection in Christ. Following St. Paul's 2 Corinthians 7, 10 Fulgentius draws a distinction between two kinds of sorrow: a harmful and a salutary one; while the former is a path leading to death, the latter produces spiritual sanity. ${ }^{32}$ Galla is exhorted to follow the precepts of her faith and avoid an indiscreet mourning over her deceased husband and realize that he is not lost but went before along the way they were both following; she is also not to regret her husband's prematurely extinguished youth: God will restore his youth as an eagle's. ${ }^{33}$

3. I am not familiar with any testimonies as to Boethius' possible knowledge of Fulgentius' letters, yet such knowledge is certainly a distinct possibility, since they were addressed to persons who formed the circle of his closest relatives and friends. What is more, these missives were in fact small spiritual treatises and the purpose they were to serve was formation of the Christian spirit of Roman aristocracy. John Moorhead questions the «romantic» vision of Boethius as a lonely, detached intellectual and states:

«The evidence we have been considering here points in a different direction. Boethius, Dionysius, and Fulgentius were all writing works of similar tendency, and can be shown to have had friends in common. It does not strain credulity to see in them and theirs friends the survivors of groups who had supported Laurentius in the schism; nor to see the deacon John, who became pope in 523, as having been among their numbers». ${ }^{34}$

It seems thus legitimate to suppose that the distinguished political and spiritual milieu that was the circle of Symmachus stood as an inspiration for Boethius not only in his political activity, but also in his literary creation. The consolatory Christian message, as found for instance in Fulgentius' letter to Galla, was highly appreciated in that environment; it is this consolatory tone that Boethius took over and intellectualized, translating it into philosophical idiom and clothing it with classical literary motifs. The result was a highly felicitous work, a

31 Ibíd. II, p. 104: «Neque enim frustra Dominus, cuius incomprehensibilia iudicia et ininvestigabiles vias apostolus praedicat Paulus, coniugem tuum religione sincera fidelem, corde humilem, moribus mitem, operibus misericordem, conversatione penitus innocentem, aetatem iuvenem, de peregrinatione huius vitae ad aeternam caelestis patriae celeriter transtulit mansionem, nisi ut, et illi gaudia aeterna conferret, et tibi facultatem melius vivendi concederet».

32 Ibíd. II, 3, p. 106: «Salubris etenim noxiaeque tristitiae debet in nostro corde manere discretio qua fit ut nec de amissione solatii temporalis concidat animus aeternis rebus deditus, et de his salubrem tristitiam sumat, in quibus se aut minus aliquid aut secus quam oportuit fecisse considerat. Propter quod Paulus utramque tristitiam non minus opere docet quam retributione discretam. Denique in una salutis proventum, in altera mortis positum demonstrat exitium dicens: Quae enim secundum Deum est tristitia paenitentiam in salutem stabilem operatur, saeculi autem tristitia mortem operatur».

33 Ibíd.II, 4, p. 108: «Ne igitur ultra fidei Christianae modum, indiscretam teneas de mariti morte tristitiam, nec amissum existimes, sed praemissum, nec ipsius iuventutem putes immature praecisam, quam interminabili vides aeternitati firmatam. Fides quippe animae dicitur: Renovabitur sicut aquilae iuventus tua».

34 J. Moorhead, Theoderic in Italy, p. 209. 
work of consolation, which, philosophical as it is, is nevertheless based on firm religious foundations, that are Neoplatonist but also Augustinian.

Susan Ford Wiltshire wrote an article on Boethius and the Summum Bonum; in it she writes:

«The discussion of the summum bonum in book 3 of the Consolatio philosophiae is dramatic both because Boethius worked it out in the extreme circumstances of his own exile and imminent execution and because he gave it such carefully wrought literary expression. A sense of the structure of the Consolatio is important in a study of the summum bonum, because Boethius' mind is working on many levels at once - philosophical, poetic, theological, dramatic. Through a synthesis of all these Boethius achieves his goal of determining the supreme good in life». ${ }^{35}$

Wiltshire suggests that much insight into Boethius' work can be gained by comparing the literary structure of the Consolatio to the structure of a classical drama. (1) The original exchange between Boethius and Lady Philosophy expands so as to incorporate a third party; Dame Fortuna (Book II, prose 2), who provides a dramatic counterpoint to Philosophy's stance; (2) the Consolatio, comprising 5 books, introduces a dramatic turnabout of action (peripeteia) halfway through the work (Book III), it is the moment when Boethius turns from despair to calm and acceptance of his deal, as he draws near to defining the Summum Bonum; (3) as is easily seen, the work includes a counterpart of dramatic chorus: every piece of dialogue in the Consolatio is summed up and commented upon by a following metric passage, which also serve to introduce new turns to the discussion and shift the argument. ${ }^{36}$

The Consolation of Philosophy opens with prisoner Boethius bewailing the wretchedness and utter injustice of his fate: his desperate predicament is a direct result of false accusation. ${ }^{37}$ $\mathrm{He}$ is plunged in sorrow and his condition he likens to senile decadence. His complaint is accompanied by the chorus of Muses of elegiac poetry:

«I who was once at the height of my powers a master of versecraft -

Woe is me! - weeping, coerced, enter the grief-ridden mode.

Lo! Their cheeks harrowed, the Muses come tell me the word I must take down,

And they now dampen my face with lachrymose elegy's truth.

Them, and them only, no panic could vanquish or frighten from coming

As my companion alone over the path I must tread.

They who were once the delight of a youth that was prosperous and happy

In my misfortunes console me, now a grieving old man».38

The self-pity the prisoner engages in is morbid and disgraceful, thus it is apposite that Dame Philosophy should come to Boethius' prison cell with a cure and consolation. She starts by chasing the plaintive Muses, who make the prisoner bewail his lost happiness and make him deaf to the voice of reason:

35 S. Ford Wiltshire, «Boethius and the Summum Bonum», in The Classical Journal, $67 / 3$ (1972), p. 216.

36 Ibíd.

37 Cf. Kijewska, A., Boethius - Divine Man or Christian Philosopher?, in M. Dzielska, K. Twardowska (eds.), Divine Men and Women in the History and Society of Late Hellenism, Kraków, 2013, p. 77 (in print).

38 Boethius, Consolation of Philosophy I, meter 1, tanslated by J. Relihan, Indianapolis, Cambridge, Hackett, 2001, 1. Cfr. Boethius, Philosophiae Consolatio I, 1, L. Bieler (ed.), Turnholti, Brepols, CCh 94, 1957, 1: «Carmina qui quondam studio florente peregi,/ flebilis, heu, maestos cogor inire modos./ Ecce mihi lacerae dictant scribenda Camenae/ et veris elegi fletibus ora rigant./ Has saltem nullus potuit pervincere terror/ ne nostrum comites prosequerentur iter./ Gloria felicis olim viridisque iuventae,/ solantur maesti nunc mea fata senis». 
«Who, she said, her pitiless eyes ablaze, let these little stage whores come visit this invalid? They do not tend to his pains with any sort of remedy; not only that, but they actually encourage them, adding their own sweet poisons. For these are the women who choke out the rich fields of reason's fruits; theirs are the barren brambles of the passions; they acclimatize the mortal mind to disease, and do not liberate it». ${ }^{39}$

The diatribe of Dame Philosophy echoes Plato's attack on mimetic art from Book 10 of his Republic (595b) - poetry is being represented as diverting mind from contemplation of the truth and leading it astray into the domain of sham and illusion. It is exactly Philosophy whose task it is to dissipate illusion, liberate the mind from mere appearance; she now appears in the prisoner's cell to remind him of his true, intellectual nature, his true destiny and restore the rule of reason in his mind. This is described as a therapy, a treatment that can be defined in terms of the Hellenistic «therapy of desire» or spiritual exercises. ${ }^{40}$ There is a strong anamnetic sense to Philosophy's therapy; by reminding him of his true identity, she liberates him from the prison of sensual immanence and leads him along the path towards the Platonic transcendence; this transcendence is man's true native land, it stands in radical opposition to «this world» and is finally and ultimately achieved through death. Philosophy's robe is marked with the Greek letter theta: this signifies both theory and «thanatos» - death; ${ }^{41}$ the supreme exemplar of philosophical detached attitude evoked by Philosophy as a model to follow, is Socrates, the sage as depicted by Plato's Phaedo. Death is no misfortune to Socrates, quite the contrary: it means the ultimate accomplishment of all philosophical strivings of a living human. Socrates' philosophy overcoming fear of death is his 'swan's song' (84e-85a) calmly delivered in the face of final departure.

This philosophical calm in the face of death is the most sublime ethical ideal left by ancient pagan philosophy. Still, we may ask: is prisoner Boethius really sincere, when following the guidance of his Mistress he strives to embrace that sublime ideal? From our human perspective we might, perhaps somewhat perversely, ask, is not that very ideal of philosophical death, the ultimate goal set for Boethius by Dame Philosophy, an ultimate consequence and product of a «morbid sorrow»?

Anyway, a decisive turnabout, a radical change of the direction of development takes place halfway through the work. In his book The Prisoner's Philosophy Joel Relihan identifies the precise moment of the decisive turn with metre 9 of Book 3: O qui perpetua. ${ }^{42}$ It is in accordance with the structure of Menippean Satire, the literary genre to which the Consolation belongs, that a radical shift, both as regards the structure and the content, should occur in the middle of the work. ${ }^{43}$ Also the roles attributed to the persons of the drama are disputed; a kind

39 Boethius, Consolation of Philosophy I, 1, p. 3; Cfr. Boethius, Philosophiae Consolatio I, 1, pp. 8-9, 2: «Quis, inquit, has scenicas meretriculas ad hunc aegrum permisit accedere, quae dolores eius non modo nullis remediis foverent, verum dulcibus insuper alerent venenis? Hae sunt enim quae infructuosis affectuum spinis uberem fructibus rationis segetem necant hominumque mentes assuefaciunt morbo, non liberant».

40 Cf. M. Nussbaum, M., The Therapy of Desire. Theory and Practice in Hellenistic Ethics, Princeton, Princeton University Press, 1994, pp. 14-15. Cf. P. Hadot, Exercices spirituels et philosophie antique, Paris, Etudes Augustiniennes, 1987.

41 Cf. Boethius, Consolation of Philosophy I, 1, pp. 2-3: «On the hem at the bottom it could be made out that the Greek letter pi had been woven in, and at the top a theta; between the two letters, after the fashion of a ladder, it could be made out that certain steps had been emblazoned, so that there could be by their means a way to climb up from the lower letter to the upper».

42 Cf. Relihan, J., The Prisoner's Philosophy. Life and Death in Boethius's Consolation, Notre Dame, University of Notre Dame Press, 2006, pp. 49, 56.

43 Cf. Relihan, J., «Late arrivals: Julian and Boethius», in Freudenburg, K., (ed.), The Cambridge Companion to Roman Satire, Cambridge, Cambridge University Press, 2005, pp. 109-110. 
of reversal takes place: in the whole of the Consolation a sort of continuous struggle for control over the work: while in the first part Dame philosophy has the initiative, the latter half of the dialogue is dominated by Boethius. ${ }^{44}$ The dialogue between Boethius and Lady Philosophy can also be viewed as an inner dialogue modeled on the Soliloquies of Augustine. It opens with Lady Philosophy comforting prisoner Boethius, but then the consolation develops into self-consolation, as though Boethius himself underwent identification with his interlocutor. ${ }^{45}$ This is how Noel H. Kaylor put it:

«The intriguingly fictional and inherently dramatic structure in which Boethius casts his work, developing his argument through a series of alternating verse and narrative passages, allows him to project his internal distress as an external dialogue between an ailing prisoner sitting in his cell, Boethius-in-the-work, and his physician-interlocutor, Lady Philosophy, who represent the emotional and rational faculties of the author, respectively». ${ }^{46}$

While I accept Relihan's and other authors' conviction as regards the central importance of Song 9 of Book 3 for the structure and meaning of the Consolation of Philosophy, I would like to enlarge the perspective in which to view this development by placing it in yet another context. The two parts into which the ninth metre of the third book breaks the whole Consolation correspond to two stages of Augustine's conversion, marking the central point of his spiritual and intellectual development as described in the Confessions. These two stages Pierre Courcelle called «conversion of the mind» and «conversion of the will» respectively. ${ }^{47}$

I would like to compare the invitation to follow the path of Platonic transcendence that Philosophy extends to Boethius in the «first half» of the Consolation to the experience Augustine described in Book 7 of his Confessions. Courcelle referred to this experience as a «failed attempt to achieve Plotinian ecstasy».48 Augustine pointed to two sources of this experience. One source was his study of «books of Platonists» which showed him the way of return to his own inner self, the other was «divine prompting» which admonished him to follow it. ${ }^{49}$ Entering the interior of his soul, Augustine saw, «with an eye of his soul» (oculo animae meae), and in fact «above the eye of his soul and above his mind, God's immutable light (lucem incommutabilem). Penetrating into this mysterious light is tantamount to being absorbed into the Truth and Eternity and it is Charity that knows both the Truth and Eternity; thus to know the eternal light is to know Truth, Eternity and Charity, that is to know God».50

44 Cf. Relihan, J., The Prisoner's Philosophy, pp. 3-4.

45 Cf. ibid., pp. 64-65.

46 Kaylor jr,. N. H., «Introduction: The Time, Life and Work of Boethius», in A Companion to Boethius in the Middle Ages, p. 26.

47 Courcelle, P., Recherches sur les «Confessions» de Saint Augustin, Paris, Edition de Boccard, 1968, p. 157.

48 Ibíd.

49 Cf. Augustinus, Confessionum liber VII, X, 16, L. Verheijen (ed.), Turnholit, Brepols, CCh 27, 1981, p. 103: "Et inde admonitus redire ad memet ipsum intravi in intima mea duce te, et potui, quoniam factus es adiutor meus». As John O'Donnell points out, the term admonitus/admonitio as used in St. Augustine's early writings indicates inspiring action by the Holy Spirit, in his later writings this term refers to actions attributable to the second person of the Trinity - Christ. Cf. O’Donnell, J. J., Augustine. Confessions. Volume II: Commentary, Oxford, Clarendon Press, 2000, p. 438.

50 Cf. Augustinus Confessionum liber VII, X, 16, p. 103: «Intravi et vidi qualicumque oculo animae meae supra eundem oculum animae meae, supra mentem meam, lucem incommutabilem [...]. Qui novit veritatem, novit eam, et qui novit eam, novit aeternitatem. Caritas novit eam. O aeterna veritas et vera caritas et cara aeternitas! Tu es deus meus, tibi suspiro die ac nocte». Brian Dobell has recently delivered a very interesting thesis (Dobell, B., Augustine's Intellectual Conversion. The Journey from Platonism to Christianity, Cambridge, Cambridge University Press, 2009, p. 23: «In my view, which I will elaborate and defend in this book, it was not until c. 395 
Fulgentius' exhortation to Eugipius to love that very Charity rests upon numerous references to Augustine. ${ }^{51}$

The language Augustine employed to describe his inner experience and the stages of his progress that he identified were both rooted in Platonism. The ultimate outcome of this experience was coming near to God, but only having experienced God's close presence Augustine was able to realize how far removed from God was his actual condition: after a brief flash of transportation he once again woke up in the «region of dissimilitude» (regio dissimilitudinis). ${ }^{52}$

It looks as though a like experience may have been familiar to Boethius as well. Encouraged by Lady Philosophy he strives to regain his true native land, to rediscover his true intellectual nature, which he has lost when he let his sorrow and regrets take mastery of him. At that moment Philosophy, in her therapeutic action first allows him to come to terms with his disturbed emotions, and then opens to his mind a vision of the universal order of the world, which is governed by the Supreme Maker (Sator), moved by benevolence:

«You who control all the world everlastingly by your own reason,

Sowing the seeds of the earth and the heavens, commanding the eons

To roll from eternity; resting unmoved you put all things in motion,

You whom no alien causes demanded to fashion creation

From mutable matter, but only the unstinting essence of true good

Planted within you». ${ }^{53}$

The order and harmony governing the universe reveal that the moving force behind the world is Love (amor), which is both the cosmic force and the power moving human beings. The praise of the love driving the cosmos appears early in Boethius' work, it is introduced in the concluding metre of Book II:

«O steadfast, trustworthy universe

Makes harmonious, ordered change

Pacts eternal restrain and curb

Warring physical elements. [...]

O how happy the mortal race,

Were Love king over all your hearts,

Love that heaven accepts as king». ${ }^{4}$

that Augustine learned how to distinguish between 'Catholic truth' and the 'falsity of Plotinus'. This is a significant claim. If it is correct, then Augustine would not have been intellectually converted to Christianity [...] until c. 395. For about ten years (386-c. 395), Augustine would have been following the Platonic path of presumption rather than the Christian path of confession».

51 Cf. Fulgence de Ruspe, Lettres ascetiques et morales V, 2-3, 228: «In spiritualibus autem donis primus fructus est caritas. [...]. Verumtamen non omnes qui caritatem mirantur et laudant, statim diligunt caritatem; et ideo, nisi eam quisque diligat, nihil ei proderit quod eam miratur et laudat. Tunc autem fructuosa est admiratio caritatis et laudatio, si non desit in admirante atque laudante dilectio».

52 Cf. Augustinus, Confessionum liber VII, X, 16, pp. 103-104: «Et inveni longe me esse a te in regione dissimilitudinis, tamquam audirem vocem tuam de excelso: 'Cibus sum grandium: cresce et manducabis me. Nec tu me in te mutabis sicut cibum carnis tuae, sed tu mutaberis in me'. [...] Et clamasti de longinquo, immo vero $e g o$ sum qui sum».

53 Cf. Boethius, Consolation of philosophy III, m. 9, p. 71. On the philosophical sources of this metre see Kijewska, A., Boethius - Divine Man or Christian Philosopher?,pp. 81-85. Cf. Boethius, Philosophiae Consolatio III, ix, pp. 51-52: «O qui perpetua mundum ratione gubernas/ terrarum caelique sator qui tempus ab aevo/ ire iubes stabilisque manens das cuncta moveri,/ quem non externae pepulerunt fingere causae/ materiae fluitantis opus, verum insita summi/ forma boni».

54 Boethius, Consolation of Philosophy II, m. 8, pp. 47-48. Cf. Boethius, Philosophiae Consolatio II, VIII, 36: «Quod mundus stabili fide/ concordes variat vices, / quod pugnantia semina/ foedus perpetuum tenent [...]. / 
This idea of the world-order effected by cosmic love is taken up in Book three. As the discussion in this book progresses, Philosophy strives to elevate Boethius the prisoner to a point whence he can view the whole world from God's perspective; in God's vision each and every thing, and, above all, each and every man is seen as endowed with his own proper place and his own purpose. At this point we are close to a renunciation of this sensible perspective upon reality which Augustine described as the regio dissimilitudinis:

«And fix the soul's vision firmly on you, vision keen and clear sighted.

Scatter these shadows, dissolve the dead weight of this earthly concretions,

Shine in the splendor that is yours alone: only you are the bright sky,

You are serenity, peace for the holy; their goal is to see you;

You are their source, their conveyance, their leader, their path, and their heaven».55

4. Book three of the De Consolatione philosophiae leads the interlocutors to the notion and vision of the Supreme Good. The blessed results of this vision are the subject matter of metre 12 of the third book, which is a veritable hymn of praise. Curiously enough, however, there appears a hint at Orpheus' fate as he gave «a backward glance to the caves of Hell» and lost the precious prize of his journey to the other world:

«O how happy the man who viewed

All the radiant source of Good;

O how happy the man who broke

All the burdensome chains of earth!

[...] Mortal men! This tale points at you,

You who seek to conduct your minds

To the light of the day above:

Let no man give a backward glance

In defeat, to the caves of Hell». ${ }^{56}$

The magnificent disclosure of love as the ultimate principle of the cosmic order in metre 9 of Book 3 paves the way for a dramatic change of direction in the intercourse between prisoner Boethius and Dame Philosophy. It is as though the dazzling perspective of transcendent beauty opened the latter makes Boethius shy away from more progress, he hesitates to follow Socrates' «swan song» to the very end. And the «conversion of the mind», if not accompanied by the «conversion of the will» ends in a momentary ecstasy followed by falling back to the regio dissimilitudinis. Relihan describes this moment of a «breakdown» in the dialogue and change of direction in the intercourse as follows:

«We are now in a good position to answer what I consider to be the fundamental question of interpretation of Consolation: whether the prisoner, as he resists Philosophy, intends a tiny point to arrive at the conclusion that he wrests from her. I would say, simply, no. In structure, the conclusion of Consolation reveals a monologic consolation finally achieved: and the gist of it, the inversion of our expectations, the vision of earth and the providential nature of all its

O felix hominum genus,/ si vestros animos amor/ quo caelum regitur regat». Cf. Ford Wiltshire, S., Boethius and the «Summum Bonum», pp. 217-219.

55 Boethius, Consolation of Philosophy III, m. 9, p.72. Cf. Boethius, Philosophiae Consolatio III, IX, p. 52: «In te conspicuos animi defingere visus./Dissice terrenae nebulas et pondera molis/atque tuo splendore mica; tu namque serenum,/ tu requies tranquilla piis, te cernere finis,/ principium, vector, dux, semita, terminus idem».

56 Boethius, Consolation of Philosophy III, m. 12, pp. 88-90. Cf. Boethius, Philosophiae Consolatio III, XII, pp. 62-64: «Felix qui potuit boni/ fontem visere lucidum,/ felix qui potuit gravis/ terrae solvere vincula./ [...] Vos haec fabula respicit/ quicumque in superum diem/ mentem ducere quaeritis./ Nam qui Tartareum in specus/ victus lumina flexerit,/quidquid praecipuum trahit/ perdit, dum videt inferos». 
phenomena, is wholly unexpected. [...] It is clear that the prisoner consciously tried to divert Philosophy from her course». ${ }^{57}$

From this point on it is Boethius who takes initiative in the intercourse with Lady Philosophy and he submits topics which definitely concern «this world»; he wants tyranny, freedom, free will, Providence and Fate, God's foreknowledge and human free decision and responsibility to come under discussion. All these points are of importance for correct understanding of the human path to the Supreme Good, however, I will here focus on just one point; the problem of free choice (liberum arbitrium). According to Boethius, two elements are indispensable for there actually existing freedom of choice in reality. These two necessary conditions of freedom are: rational judgment (iudicium) ${ }^{58}$ and absence of coercion - selfdetermination. ${ }^{59}$ This implies that freedom is gradable according to the degrees of strength and clarity of one's understanding of a given situation and according to self-determination. The supreme freedom is only attributable to God, who is omniscient and absolutely selfsufficient; God, the paradigm of freedom is the ideal pattern for human conduct. The closer man becomes to God and God's perspective on things, the more he extends the field of free action open to him. Song 9 from Book 3 of the Consolation represents an attempt to see the world from God's perspective, and what follows is an effort to measure the field of freedom open to human beings in search of perfect self-sufficiency (sufficientia) ${ }^{60}$

The perfect model of self-sufficiency is again God, the Supreme Good. As he first introduces the concept of highest good, Boethius is inclined to the Aristotelian construal of this concept: Summum Bonum is the ultimate objective of all striving and all actions (Nicomachean Ethics 1097b); ${ }^{61}$ however, he soon moves towards a «Platonic turn». Boethius identifies the Supreme Good with God, with beatitude and the ultimate source of all beatitude. All goods found in the world and contributing to happiness are just aspects of God's goodness. ${ }^{62}$ It is self-evident to Boethius that supreme goodness can only be realized in God, as God is the supreme perfect being, than whom no more perfect, no «better» can be found on pain of infinite regress. ${ }^{63}$ It is also self-evident that the Supreme Good is beatitude, or perfect happiness, since perfect happiness exists in God and is identical with God. ${ }^{64}$

57 J. Relihan, The Prisoner's Philosophy, p. 80.

58 Cf. Boethius, Commentarii in librum Aristotelis Peri hermeneias, editio secunda III, 196, C. Meiser (ed.), Lipsiae, 1880, vol. 2, p. 196: «Nos autem liberum voluntatis arbitrium non id dicimus quod quisque voluerit sed quod quisque judicio et examinatione collegerit. Alioquin multa quoque animalia habebunt liberum voluntatis arbitrium. Illa enim videmus sponte quaedam refugere, quibusdam sponte concurrere. Quod si velle aliquid vel nolle hoc recte liberi arbitrii vocabulo teneretur, non solum hoc esset hominum sed caeterorum quoque animalium, quibus hanc liberi arbitrii potestatem abesse quis nesciat?». Cf. Marenbon, J., Boethius, pp. 123-124.

59 Boethius, Commentarii in librum Aristotelis, III, 195: «Et de libero quoque arbitrio eadem nobis paene illisque contentio est. Nos enim liberum arbitrium ponimus nullo extrinsecus cogente in id quod nobis faciendum vel non faciendum indicantibus perpendentibusque videatur, ad quam rem praesumpta prius cogitatione perficiendam et agendam venimus, ut id quod fit ex nobis et ex nostro iudicio principium sumat nullo extrinsecus aut violenter cogente aut impediente violenter».

60 Cf. Asbell jr.,W. J., «The Philosophical Background of sufficientia in Boethius' Consolation, book 3», in New Direction in Boethian Studies, pp. 3-7.

61 Cf. Boethius, Consolation of Philosophy III, 10, p. 72 ff.; cf. Boethius, Philosophiae Consolatio III, 10, pp. 40, 55: «Cum igitur omnia boni gratia petantur, non illa potius quam bonum ipsum desideratur ab omnibus».

62 Cf. Asbell jr., W. J., The Philosophical Background of sufficientia in Boethius' Consolation, book 3, p. 9.

63 Boethius, Consolation of Philosophy III, 10, p. 76; cf. Boethius, Philosophiae Consolatio III, 10, pp. 10, 53: «Quare ne in infinitum ratio prodeat, confitendum est summum deum summi perfectique boni esse plenissimum».

64 Ibíd. III, 10, p. 76: «For this same true happiness is judged to be the highest self-sufficiency, the highest power, the highest preeminence as well, and renown and physical pleasure. Well then: Are all these 
Furthermore this Supreme Good is a person, ${ }^{65}$ and the best way of approaching this Person and getting in touch therewith is attitude of humility and prayer. Joel Relihan points to this personal conception of supreme goodness, and to the concealed presence of other Christian motifs as an attempt to find a possible way out of the maze of philosophy: Boethius' response to the limits of philosophical discourse and inability of the latter to respond to human needs appears to be the Christian way of humble prayer. ${ }^{66}$ This may be a lesson learned from St. Augustine, whose «conversion of the will», described in the famous «Milan garden scene» was accomplished with the help of prayer, when, asking God for help, he receives an answer in the form of a child's voice prompting him to take and read the book that lay by his side, that is St. Paul's Epistles.

Joel Relihan arrives at the conclusion that the De Consolatione is not an ordinary philosophical treatise of consolation, nor is it a piece of protreptic literature; in fact, Boethius' Consolation is a place of combat between two opposite strivings: a striving towards transcendence, represented and embodied by Dame Philosophy, and a search for some justification of human reality by means of a theodicy, some justification of God's ways towards the world given the evil present therein, ${ }^{67}$ that motivates prisoner Boethius' queries.

In this context W. Helleman's interpretation of Lady Philosophy is of particular interest. Here Boethius' Philosophy is a medical woman, a teacher of virtues, the font of wisdom and knowledge, which, naturally, seems traditional enough. She comes in a company of other classical personifications of philosophical wisdom as female figures, including Plato (Republic 595d-e), Cicero and Seneca. Nor is the Bible absent in her account: it is represented by the unforgettable picture of the Divine Wisdom, «the designer of all things», «the untarnished mirror of God's majesty», «the faithful image of his goodness». ${ }^{6}$

The first exegete to identify this transcendent wisdom with God's Mind was Philo of Alexandria, his lead was soon followed by the Church Fathers with, above all, Alexandrians and St. Augustine. Helleman suggests that the Boethian Dame Philosophy is an outcome of that Jewish and Christian tradition and she sees in her a figure of Christ, in whom the human and divine elements came to form unity. The Christ, who was the divine Logos assumed human body, in Him divine and human traits became inseparable. Much in the same way Dame Philosophy from the De Consolatione represents a unity of the human and the divine. Her speech, discourse, medical approach to the human patient she looks like embodiment of divine grace leading man towards divine life and liberty. Her function is much the same as Christ's, thus she can be considered to be His type, an embodiment of His presence. ${ }^{69}$

The message that Boethius puts forward through the means of his Consolation and the utterances he puts in the mouth of his Dame Philosophy are not far removed from the advice offered by Fulgentius to Proba. She, too, was encouraged to acknowledge her own weakness and lack of sufficiency, to contrition, to humble trust in wisdom and guidance of God, who is

things, self-sufficiency, power, and the rest, certain kinds of limbs, as it were, of the body of happiness, or are they all to be understood in reference to the Good, their head, as it were?».

65 Cf. ibíd. III, 10, p. 75: «Therefore, every truly happy person is God. But, to be sure, God is one by nature; however, nothing prevents there being as many gods as you please by participation».

66 Cf. Relihan, J., The prisoner's Philosophy, XII.

67 Ibíd., p. 84. Cf. Blackwood, S., «Prayer in Boethius' “Consolation of Philosophy”, Dionysius, 20 (2002), p. $150 \mathrm{ff}$.

68 Wisdom, 7, pp. 21-26; cf. Helleman, W. E., The Feminine Personifications of Wisdom. A Study of Homer's Penelope, Cappadocian Macrina, Boethius' Philosophia and Dante's Beatrice, Lewiston, N.Y., Edwin Mellen Press, 2009, pp. 174-179.

69 Ibíd., p. 190. 
the best of all doctors..$^{70}$ Is Dame Philosophy's message not very much alike? Did not Alcuin, who regarded himself as a faithful «disciple» of Boethius, share a conception of philosophy as the «teacher of virtues» and wisdom, as the one who leads man along the path of wisdom towards the Divine light? ${ }^{71}$

Fecha de recepción: día 25 de junio de 2014

agnieszka.kijewska@kul.lublin.pl

Fecha de aceptación: día 25 de septiembre de 2014

70 Cf. Fulgence de Ruspe, Lettre III; Lettre IV, 1, pp.153 ff, 206.

71 Cf. Courcelle, P., La «Consolation de la philosophie», p. 37; Alcuin, Grammatica, PL 101, 849 C-850 A: «Saepius te dicentem quod philosophia esset omnium virtutum magistra, et haec sola fuisset quae inter omnes saeculi divitias nuquam miserum se possidentem reliquisset. Incitasti nos, ut vere fatemur, his dictis ad tam excellentis felicitates indagationem, scire cupientes quae esset huius magisterii summa, vel quibus gradibus ascendi potuisset ad eam. [...] Oculi itaque si splendore solis, vel alia qualibet lucis praesentia asperguntur, perspicacissime, quidquid obtutibus occurrit, discernere valent: caeterum sine lucis accessu in tenebris manere notissimum est. Sic animi vigor acceptabilis est sapientiae, si erit qui eum illustrare incipiat». 